\section{Sugar Industry of the Caribbean}

Sugar still occupies the first place in Caribbean economy, despite the severe and growing competition in other parts of the world. The factors concerned with this economy are considered at length in "The Sugar Industry of the Caribbean", compiled by the Caribbean Research Council (Washington, D.C., 1947. Crop Inquiry Series No. 6). Some Caribbean territories have been unable to withstand competition and have given up sugar cultivation, whereas in others there has been an increase; but increase is most noted in production, not acreage. This has been greatly helped by research work on new varieties more resistant to disease, and the study of pests. Cane breeding is now active in Barbadoes, British Guiana and Puerto Rico. Experimental work with various fertilizers has had useful results, and there has been a great increase in the import of fertilizers. Sulphate of ammonia is the chief fertilizer. The estates without manure now form a minority. Another change in the industry of cane-growing is the increase in mechanization, especially in United States territories. Weeding and harvesting are still done largely by hand. Generally speaking, there is great scope for the use of more machinery as well as for the centralization of production.

\section{Development of British Somaliland}

THE report on the General Survey of British Somaliland, 1946, conducted under Approved Scheme D484, Economic Survey and Reconnaissance, under the Colonial Development and Welfare Act, records that the 1946 rainfall was higher than average and well distributed (British Military Administration, Burao, Somaliland. Pp. $20+12$ pl. 6s.). Tribes tended to move more to south-west than south-east and not so far afield from the Protectorate as in the previous two years. This was due to better rainfall in and near the Protectorate, and resulted also in a drawing in of Somali tribes towards British Somaliland. Rainfall and tribal migration maps are appended to the report. Development of water supplies and some minerals should be possible in 1947-48, and if the survey is continued until the end of 1950 , a more balanced report, based on the records of a seven-year cycle, should be possible and facilitate the making of definite proposals for developing the country.

\section{Medical Progress in Chile}

THE Medical Faculty of Valparaiso, formed after a meeting of Chilean medical men convened in March 1912, by Dr. Frederico Engelbach, has, since its formation, planned the publication of an official scientific journal; but for various reasons this has not been possible until this year. Now the first number of this vigorous Faculty's journal, Revista Medica de Valparaiso, has appeared. Well printed and tastefully produced, it will appear in February, May, August and November each year and will publish only scientific papers. As the Faculty's president, Dr. R. Gajardo Tobar, says in his editorial, its pages are dedicated to those who have studied phenomena with objective criticism and express their results with the greatest possible precision. The new journal will record the more important themes presented to the Faculty, summaries of the Faculty's meetings and articles by individuals invited to contribute. This first number contains articles on hypertension of nephritic origin, streptomycin and tuberculous meningitis, the therapeutic action of urethane in leukæmia, and varicose veins and their treatment. Medical men in both the Old and the New Worlds will welcome this new record of the work being done in Chile.

\section{British Agricultural Bulletin}

British Agricultural Bulletin is a new, illustrated quarterly journal published by the British Council. It is intended for overseas circulation, particularly with a view to the needs of agricultural adminis. trators, university and agricultural college teachers, research workers and large-scale farmers, none of whom have time to digest the vast specialist literature of to-day. In the words of Prof. J. A. Scott Watson's editorial note, its aim is "to put British knowledge and experience at the disposal of the farmers and citizens of other countries" and thus to help them in their efforts to increase the world's food supply. The articles in the first number (Spring 1948) cover a wide field and are written by specialists on the subject in each case. General principles of animal improvement, war-time farming in Cheshire, the resting break in farming systems and new ideas in grain storage are discussed in some detail, while of more general interest is the account given of the aims and organisation of the National Agricultural Advisory Service set up in Britain in 1946. Reviews and advertisements of books form a prominent feature, and a special article in this number is devoted to modern English books on agriculture. In future issues, it is hoped to give some account of such new technical developments or scientific discoveries as seem ready for application to farm practice, and to discuss matters of agricultural finance, economics and education in terms intelligible to the layman. The price for four numbers will be 15s. (including postage), payable to the British Council, 3 Hanover Street, London, W.1.

\section{Irish Chemical Association Summer School}

A Summer School organised by the Irish Chemical Association and held in Dublin during July 5-9 attracted 130 participants, of whom some thirty came from universities, hospitals and industrial concerns in Great Britain. The courses covered recent advances in various branches of chemistry. Dr. V. C. Barry, research fellow of the Medical Research Council of Ireland, dealt with the subject of chemotherapy with particular reference to tuberculosis. During his lectures he discussed some of the results obtained by the active school in Dublin of which he is the head (see Nature, 160,$800 ; 1947$ ). Lectures were given on recent advances in the technique of organic chemistry by Prof. W. Cocker, professor of chemistry, Trinity College, Dublin. The last lecture of this particular series was delivered by Mr. E. R. Stuart, Trinity College, Dublin, who surveyed the methods of application of infra-red and ultra-violet radiation to the determination of the structure of organic compounds. Prof. E. J. Conway, professor of biochemistry and pharmacology, University College, Dublin, who has recently returned from a lecture tour in the United States, discussed biological oxidation and reduction, the nature of the cell membrane and the chemical interpretation of the action of hormones and vitamins, and concluded his course with a lecture on the biochemical approach to carcinogenesis. Prof. T. S. Wheeler, professor of chemistry, University College, Dublin, in a course of five lectures, gave a simplified account of the mathematical background of wave mechanics and described 